\title{
May God have mercy on us all
}

\author{
Andrew R Potter
}

A young man walks into my clinic. I greet him and ask what is wrong. He looks me straight in the eyes, just for a moment, as if to test the waters. He then looks away. "J'ai le chaud de pisse." He lifts his eyelids a second time to judge my response. I give no hint of surprise and pose one or two more questions. After a relevant examination it is clear that this is an uncomplicated case of gonorrhoea. I quiz him on his partner and elicit one of the standard responses, "She's gone back home" $(60 \mathrm{~km}$ away); "she's returned to Zaire" (across the river); or "a girl I met in Bangassou on my way back from the capital." The partner is never acknowledged to be someone local because our patient knows that we would then pressure him to bring her along and pay for the double treatment. So much for contact tracing. I prescribe penicillin and probenecid and hand him back his card. "Have you heard of the illness called SIDA?" I inquire before he leaves the room. He nods, so I continue "Gonorrhoea we can cure, but SIDA is fatal and you get it in the same way. Stay faithful to your wife."

\section{... she smiles and I know that I am wasting my breath.}

She is well dressed despite having no job and little education. This marks her out straightaway from most of my other patients. And when I ask her to lie down for an examination there is no hint of modesty or embarrassment as she lies supine with her bare legs wide apart. Not surprisingly she has pelvic inflammatory disease. My assistant tells me that she has done the rounds of all the local "fonctionnaires" and the more good looking of the older college students. If she asked for money we'd call her a prostitute. She never asks, but certainly expects a gift to arrive sometime later, be it a set of earrings, an ivory bracelet, or a pair of shoes. Almost anything is acceptable. She doesn't really want cash. I repeat my little piece about the new dangers of such an abandoned lifestyle. She smiles and I know that I'm wasting my breath.

It is perhaps our geographical isolation in this corner of central Africa that has up until now shielded us from the AIDS epidemic. I have suspected overt disease in only two or three patients, but we hear of many cases in Bangui, the capital, and in some of the major towns. My fear is that until we begin to see larger numbers of cases people will not take our warnings seriously. We have been told by those who should know better that "SIDA is only an invention of you missionaries to force us to behave as you want." Many of our young people also doubt us. To them SIDA is "syndrome imaginaire pour décourager les amoureux."

Perhaps the word promiscuous carries moralistic overtones and should therefore be avoided. It at least conveys the idea of frequent changes of loyalty. I live among people who have multiple sexual partners both before and after marriage. Most girls have lost their virginity by the age of 12 . No one marries a virgin. By the age of 20 a young man may easily have had several dozen partners. Some parents refuse to send their daughters to secondary school because teachers expect their pupils to allow them physical favours. Should the girl refuse she will fail to get sufficient marks in her examinations and will be required to repeat the year in the same class. In one town I visit the African doctor was refused the opportunity to instruct pupils in venereal diseases by members of the teaching staff.

I am pessimistic that health education, which is the only weapon available to us in combating AIDS, will have any impact in this milieu. Our people believe in their heart of hearts that illness comes as a result of witchcraft and curses and indigenous "medicine." Whenever someone dies the family holds council in order to find out who was responsible for the death. When we breeze in and talk about bacteria and viruses, which cannot be seen, we are looked at in disbelief. Perhaps it is just possible to comprehend cause and effect in, for example, gonorrhoea when the urethral pus and dysuria appear within a day or two of sexual intercourse. But it is stretching credulity too much to say that you might fall ill several years after a five minute fling during the Saturday night disco when there have been no symptoms at all. Of course you might die. Death is around us every day from malaria, hepatitis, tuberculosis, and a hundred other things. Why not eat, drink, and be merry first?

We encourage the use of condoms. These are not available outside the large towns, and they are expensive. Neither the girls nor the boys like them anyway. As a sous prefet told $m e$ in front of several others, "I like the sensation of flesh against flesh." Everyone roared with laughter. We counsel the avoidance of intercourse with partners who have genital ulcers. But sex out here is not performed in well lit Laura Ashley bedrooms, only in dark mud huts quickly and furtively. You simply don't inspect the partner first. I also advise girls to avoid soldiers and others coming from the big cities. The girls, however, relish just such prospects as they are much more likely to have money and goodies for them. In a society where sex is for the asking boys do not learn to masturbate. Why should they when girls are so eager? When a boy reaches puberty he is expected to leave the parental home and build his own smal mud brick house and live there alone. Where better to realise teenage fantasier? $\mathrm{Ex}$ patriates do not always set a good example. At a recent party for the Peace Corps in our capital city, where booze and drugs were freely available, young African men were given the chance to fulfil their dreams and bed white girls. One young fellow I spoke to had scored three times, and on one occasion the American girl tore off his condom first.

\section{. . . sex out here is not performed in well lit Laura Ashley bedrooms.}

I write all this not to shock or exaggerate. It is all fact, unfortunately. The question is, Can anything be done to change the position or are we here doomed to lose a whole generation? If I were some fiendish madman wishing to exterminate mankind I could think of no better ploy than to dream up a virulent organism transmitted by sexual contact with a long symptomless incubation period and then let it loose in an amoral society. I am also unnerved when I consider my own position: a single man, living in central Africa, operating on more than four hundred patients each year. I often find at the end of surgery that there are holes in my gloves and blood on my fingers. Who would insure me? May God have mercy on us all.

Andrew $R$ Potter is a doctor working in the Central African Republic 